Research Article

\title{
Pengembangan Media Pembelajaran Berbasis Android pada Materi Transkripsi dan Translasi untuk Mata Kuliah Genetika
}

\author{
The Development of Android-Based Learning Media in Transcription and Translation \\ Material for Genetic Courses

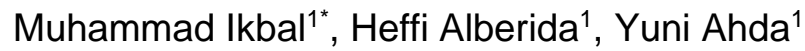 \\ 1 Jurusan Biologi, Fakultas Matematika dan Ilmu Pengetahuan Alam, Universitas Negeri Padang, Padang, \\ West Sumatra, Indonesia \\ *email: 15muhammad.ikbal@gmail.com
}

Kata Kunci:

Media Pembelajaran

Android

Genetika

Transkripsi

Translasi

Key Words:

Learning Media

Android

Genetics

Transcription

Translation

Submitted: 06/05/2021

Revised: 16/05/2021

Accepted: 18/05/2021

\begin{abstract}
Abstrak. Materi biologi banyak menjelaskan konsep abstrak seperti proses fisiologis hingga molekuler membuat materi biologi dianggap sulit oleh mahasiswa. Berdasarkan hasil observasi dan wawancara yang telah dilakukan, masih banyak mahasiswa menganggap materi pada matakuliah genetika sulit terutama pada materi transkripsi dan translasi. Mahasiswa membutuhkan media vang praktis untuk digunakan dimanapun dan kapanpun serta mampu memvisualisasikan materi tersebut. Media pembelajaran berbasis Android diharapkan mampu meningkatkan pemahaman mahasiswa terhadap materi transkripsi dan translasi. Penelitian ini merupakan Research and Development menggunakan model 4D, namun pada penelitian ini dibatasi hanya tiga tahapan yaitu Define, Design dan Develop, khususnya sampai validasi produk. Produk media yang dikembangkan berupa media pembelajaran dengan format aplikasi .apk yang bisa dioperasikan pada perangkat smartphone Android dan pada perangkat laptop/PC menggunakan software emulator seperti NOX dan lainnya. Media pembelajaran ini memuat materi transkripsi dan translasi yang terdiri dari menu-menu yaitu: Learning Outcomes (LO), materi (memuat penjelasan serta proses transkripsi dan translasi), latihan (berupa soal-soal dalam bentuk multiple choises), dan tombol keluar. Berdasarkan uji validitas didapatkan hasil validiasi dari ahli materi $97,5 \%$ dengan kategori sangat valid dan ahli media juga dapat dikategorikan sangat valid sebesar $83.8 \%$. Berdasarkan hasil tersebut didapatkan angka validitas sebesar $91,2 \%$ dengan kategori sangat valid.
\end{abstract}

Abstract. Biology learning material explains a lot of abstract concepts
such as physiological to molecular processes, making biological material
difficult for students. Based on the results of observations and interviews
that have been carried out, there are still many students who think that
the material in genetics is difficult, especially in transcription and
translation. Students need practical media to be used anywhere and
anytime and be able to visualize the material. Android-based learning
media is expected to increase students' understanding of transcription
and translation materials. This research is a Research and Development
using a $4 D$ model, but in this study it is limited to only three stages, 
namely Define, Design and Develop, especially to product validation. The media product developed is in the form of learning media with apk application format that can be operated on Android smartphone devices and on laptop/PC devices using emulator software such as NOX and others. This learning media contains transcription and translation material consisting of menus, namely: Learning Outcomes (LO), material (containing explanations and transcription and translation processes), exercises (in the form of questions in the form of multiple choices), and exit buttons. Based on the validity test, the validation results from material experts are $97.5 \%$ with a very valid category and media experts can also be categorized as very valid at $83.8 \%$. Based on these results, the validity number is $91.2 \%$ with a very valid category.

This is an open access article distributed under the Creative Commons 4.0 Attribution License, which permits unrestricted use, distribution and reproduction in any medium, provided the original work is properly cited. (02021 by author.

\section{PENDAHULUAN}

Teknologi informasi dan komunikasi beberapa tahun belakangan ini berkembang pesat dan mendorong adanya inovasi di segala bidang kehidupan. Salah satu bidang kehidupan yang tidak bisa terlepas dari perkembangan tersebut adalah dunia pendidikan. Kehadiran teknologi multimedia diharapkan dapat mengembangkan potensi peserta didik secara optimal, sehingga proses pembelajaran jauh lebih menarik, bermakna, dan tercapainya tujuan pembelajaran (Munir, 2012).

Keterbatasan ruang dan waktu selalu menjadi kendala dalam pelaksanaan pembelajaran. Kehadiran teknologi yang menghadirkan perangkat mobile seperti smartphone, tablet dan laptop/PC bisa menjadi solusi terhadap kendala tersebut. Hal ini karena perangkat mobile memiliki fleksibilitas, konektivitas dan portabilitas yang tinggi sehingga memungkinkan peserta didik dapat mengakses materi pembelajaran dimanapun dan kapanpun (Zaheer, Butt, Anatolyevna, \& Salmani, 2018). Selain itu perangkat mobile juga dilengkapi dengan fitur berupa multimedia sehingga materi yang bersifat abstrak menjadi lebih konkret karena disajikan dalam bentuk gambar, video atau animasi yang dilengkapi dengan suara (Setiawan, Alimi, Alimah, Kurniawan, \& Zahro, 2015).

Berdasarkan hasil survei secara online dimulai tanggal 28 Oktober 2020 pada mahasiswa Jurusan Biologi FMIPA UNP tahun masuk 2016, 2017 dan 2018 didapatkan hasil bahwa 100\% mahasiswa memiliki perangkat smartphone dan 83,4\% memiliki perangkat laptop/PC. Hal ini karena perangkat laptop/PC memiliki harga yang relatif mahal, ukuran yang besar dan berat, tidak praktis karena sulit untuk dibawa, digunakan dimana saja dan kapan saja. Sedangkan smartphone memiliki harga lebih murah dibandingkan laptop/PC, ukuran yang kecil dan ringan, praktis, serta bisa digunakan dimana saja dan kapan saja. Selain itu perkembangan jaringan seluler semakin pesat yang memungkinkan konektivitas yang luas dan cepat (Noviar, 2016).

Sistem operasi (operating system/OS) yang banyak digunakan pada smartphone mahasiswa Jurusan Biologi FMIPA UNP adalah Android OS dengan total persentase 92,7\% disusul oleh iOS dan Windows Mobile Phone (Microsoft) masing-masing $6 \%$ dan 1,3\%. Android merupakan sistem operasi yang banyak digunakan di Indonesia dengan persentase 92,14\% 
sedangkan OS lainnya seperti iOS hanya $8,7 \%$ (Statcounter, 2020). Hal ini disebabkan karena OS Android bersifat opensource dan penggunaannya praktis dan mudah dimengerti (Yektyastuti \& Ikhsan, 2016).

Rata-rata penggunaan smartphone pada mahasiswa mencapai 5-10 jam perhari, sedangkan penggunaan PC ratarata kurang dari 5 jam perhari. Lama durasi penggunaan smartphone ternyata belum dimanfaatkan secara optimal untuk mendukung proses belajar. Hal ini sejalan dengan hasil penelitian Fadri (2018) bahwa ada umumnya mahasiswa menggunakan smartphone, laptop/PC untuk sarana komunikasi, hiburan serta bermain game.

Materi biologi merupakan materi yang sangat kompleks. Kebanyakan materi biologi bersifat abstrak karena membahas struktur, proses fisiologi, dan komponen kimiawi organisme berukuran besar sampai organisme mikroskopik. Hal tersebut membuat materi biologi dianggap sulit oleh mahasiswa. Salah satu materi biologi yang dianggap sulit oleh mahasiswa adalah materi transkripsi dan translasi dalam sintesis protein. Berdasarkan hasil penelitian pendahuluan yang dilakukan, materi genetika yang dianggap paling sulit oleh mahasiswa adalah pada materi sintesis protein. Sebanyak 58,3\% mahasiswa menyatakan tidak paham proses sintesis protein. Hal ini menurut mahasiswa disebabkan karena kurangnya media. Hal ini dapat terlihat dari ketercapaian hasil belajar mahasiswa Jurusan Biologi FMIPA UNP pada materi transkripsi dan translasi, sekitar $58,6 \%$ nilai mahasiswa tergolong dalam kategori rendah. Biologi molekuler dianggap memiliki tingkat kesulitan yang tinggi oleh mahasiswa disebabkan oleh belum sesuainya antara proses pembelajaran yang digunakan dengan penggunaan bahan ajar yang belum sesuai dengan kebutuhan mahasiswa (Mahmudati, 2015). Materi sintesis protein dianggap sulit karena materi yang bersifat abstrak, banyak membahas proses, sehingga dibutuhkan media untuk mendeskripsikan atau memvisualisasikan proses tersebut (Cavalho, Beltramini, \& Bossolan, 2018).

Penggunaan media pembelajaran pada proses perkuliahan masih memiliki kendala dan keterbatasan. Berdasarkan hasil wawancara yang telah dilakukan dengan dosen mata kuliah Genetika Jurusan Biologi FMIPA UNP, dosen menggunakan media yang masih tergolong sebagai media noninteraktif. Pada umumnya dosen menggunakan media seperti buku teks, slide power-point, dan video dari You-Tube. Hal ini sejalan dengan hasil penelitian Sophia (2019) bahwa media seperti buku teks dan slide power point tidak efektif karena mahasiswa harus membawa dan mencari materi yang dibutuhkan pada halaman terkait atau membuka perangkat laptop/PC. Adapun salah seorang dosen yang menggunakan multimedia interaktif berbasis flash namun penggunaanya masih belum efektif. Hal ini disebabkan mahasiwa hanya bisa mengoperasikan media tersebut pada perangkat laptop/PC sehingga mahasiswa membutuhkan tempat untuk menjalankannya.

Akibat dari permasalahanpermasalahan yang ditemukan tersebut berimbas kepada nilai mahasiswa. Hasil wawancara dengan salah seorang dosen pengampu mata kuliah Genetika didapat data nilai mahasiswa pada umumnya tergolong rendah. Sebanyak 58,9\% mahasiswa mendapat nilai rendah pada mata kuliah Genetika. Hal inilah yang menyebabkan banyak mahasiswa mengulang untuk memperbaiki nilai pada mata kuliah ini. 
Kehadiran teknologi berupa smartphone diharapkan bisa menjadi solusi terhadap kendala yang ditemukan pada perkuliahan Genetika. Smartphone bisa dimanfaatkan untuk mengoperasikan multimedia interaktif berbasis aplikasi Android yang dibuat menggunakan software Adobe Flash Professional CS6. Aplikasi ini juga dapat dijalankan untuk membuat grafis dan animasi yang sangat menarik dan bisa dilengkapi dengan media lainnya seperti teks, gambar, grafis, suara, dan video sehingga sangat cocok digunakan untuk mengembangkan multimedia interaktif. Penggunaan aplikasi berbasis Android sebagai media pembelajaran memiliki kelebihan, yakni bersifat mobile dengan kemudahan aksesnya (Haryono et al., 2021). Media pembelajaran berbasis Android yang dibuat menggunakan Adobe Flash Professional CS6 berbeda dengan media pembelajaran lainnya karena adanya interaksi antara media dan pengguna sehingga dapat meningkatkan motivasi dan pemahaman peserta didik (Astuti \& Nurcahyo, 2019).

Media pembelajaran berbasis Android yang telah dikembangkan ini nantinya diharapkan mampu menjadi solusi bagi dosen untuk membantu meningkatkan pemahaman mahasiswa dalam materi transkripsi dan translasi. Hal ini sejalan dengan hasil penelitian Pahlifi (2019) bahwa media pembelajaran berbasis Android dapat meningkatkan pemahaman, memori dan motivasi belajar peserta didik karena media tersebut bisa memfasilitasi peserta didik dimanapun dan kapanpun serta dapat diulang-ulang. Penelitian ini bertujuan untuk mengembangkan media pembelajaran yang valid pada materi transkripsi dan translasi untuk mata kuliah genetika di Jurusan Biologi FMIPA UNP.

\section{METODE}

Penelitian ini merupakan Research and Development menggunakan model pengembangan 4D. Tahapan penelitian yang dikembangkan oleh Thiagarajan (1989) ini terdiri atas empat tahapan yaitu: 1) Define, 2) Design, 3) Develop, dan 4) Dissaminate (Fitriana, Amelia, \& Marianingsih, 2017). Penelitian ini dilakukan hanya sampai tahap develop saja karena keterbatasan waktu dan biaya, khusunya dibatasi sampai tahap validasi produk oleh pakar. Tahapan penelitian ini yaitu: (1) Define (pendefinisian), bertujuan untuk menetapkan dan mendesinisikan syaratsyarat pembelajaran, tahapan ini meliputi a) front-end analyse, b) analisis peserta didik, c) analisis tugas, d) analisis konsep dan e) analisis tujuan pembelajaran; (2) Design (perancangan), bertujuan untuk menyiapkan purwarupa media yang akan dibuat; (3) Develop (pengembangan), bertujuan untuk mengembangkan dan menghasilkan media yang sudah diperbaiki berdasarkan rekomendasi dari beberapa orang pakar yang terdiri dari ahli dalam bidang genetika molekuler dan media pembelajaran. Produk yang dihasilkan berupa media pembelajaran berbasis Android pada materi transkripsi dan translasi untuk mata kuliah genetika di Jurusan Biologi FMIPA UNP.

Instrumen penelitian yang digunakan berupa angket uji validitas yang menilai produk pada aspek kualitas tampilan, kualitas media, interface, kurikulum, penyajian materi, evaluasi, dan kebahasaan. Sebelum angket dalam penelitian ini digunakan, terlebih dahulu divalidasi oleh salah seorang validator. Aspek yang dinilai adalah kelayakan isi dan kebahasaan. Berdasarkan hasil uji validasi instrumen, didapatkan nilai validitas instrumen sebesar 100\% dengan kategori sangat valid dan dapat disimpulkan bahwa 
angket telah bisa digunakan tanpa adanya perbaikan.

Analisis validitas angket menggunakan skala Likert dengan kategori positif, dengan setiap jawaban mempunyai bobot sebagai berikut:

Tabel 1. Tabel Bobot Pernyataan Validasi

\begin{tabular}{ll}
\multicolumn{1}{c}{ Angket Validitas } & \\
\hline \multicolumn{1}{c}{ Pernyataan } & Bobot \\
\hline Sangat Setuju (SS) & 5 \\
Setuju (S) & 4 \\
Cukup Setuju (CS) & 3 \\
Tidak Setuju (TS) & 2 \\
Sangat Tidak Setuju (STS) & 1 \\
\hline
\end{tabular}

(Setiana \& Hansun, 2017).

Data hasil validasi kemudian dianalisis menggunakan teknik deskriptif analisis yang berpatokan pada kriteria pada Tabel 2 berikut.

Tabel 2. Tabel Kriteria untuk Menentukan Kualitas Validitas Produk

\begin{tabular}{ll}
\hline \multicolumn{1}{c}{ Skor (\%) } & \multicolumn{1}{c}{ Kategori Kelayakan } \\
\hline $81 \%-100 \%$ & Sangat valid \\
$61 \%-80 \%$ & Valid \\
$41 \%-60 \%$ & Cukup valid \\
$21 \%-40 \%$ & Tidak valid \\
$<20 \%$ & Sangat tidak valid \\
\hline
\end{tabular}

(Fitriana, Amelia, \& Marianingsih, 2017).

Perhitungan data nilai validitas dianalisis dalam skala (0-100) dengan berpatokan pada rumus sebagai berikut (Yektyastuti \& Ikhsan, 2016):

Keterangan:

$$
\text { Nilai Validitas }=\frac{x}{y} \times 100 \%
$$

$X=$ skor yang diperoleh

$\mathrm{Y}=$ skor maksimal.

\section{HASIL DAN PEMBAHASAN}

\subsection{Tahap Define}

Kegiatan pada tahap ini dilakukan untuk menetapkan serta mendefinisikan syarat-syarat pengembangan. Dalam model lain, tahapan ini juga dinamakan analisis kebutuhan (needs assessment). Analisis kebutuhan merupakan proses secara formal untuk menentukan jarak atau kesenjangan antara keluaran (output) dengan dampak nyata (Arikunto \& Jabar, 2012). Analisis kebutuhan yang dilakukan adalah sebagai berikut.

\section{Front-End Analysis}

Materi transkripsi dan translasi yang bersifat abstrak dan menjelaskan tentang proses membuat materi ini membutuhkan media untuk membantu mahasiswa dalam memahami materi ini. Berdasarkan hasil penelitian pendahuluan didapatkan data bahwa sebanyak 58,3\% mahasiwa tidak paham materi transkripsi dan translasi, hal ini dapat terlihat dari hasil ketercapaian belajar pada materi ini dan nilai mahasiswa pada mata kuliah genetika umumnya tergolong rendah.

Media pembelajaran yang digunakan saat perkuliahan masih belum berbasis Android. Adapun salah seorang dosen yang menggunakan multimedia berbasis flash saat perkuliahan namun penggunaannya tidak praktis karena hanya bisa dijalankan pada perangkat laptop/PC sehingga mahasiswa butuh tempat untuk mengoperasikannya. Selain itu minat mahasiwa untuk mencari media selain yang diberikan oleh dosen juga tergolong rendah, $37,1 \%$ mahasiswa tidak mencari sumber belajar selain yang telah ditetapkan oleh dosen, sebanyak 62,3\% mahasiswa tidak mempersiapkan diri untuk mengikuti perkuliahan genetika, bahkan 48,4\% mahasiswa tidak meminta media slide power point dosen untuk memambah pemahaman materi.

Mahasiswa membutuhkan media yang mampu memvisualisasikan materi tersebut serta praktis digunakan dimanapun dan kapanpun. Selain itu keterbatasan jumlah perangkat laptop/PC juga menjadi kendala 
karena tidak semua mahasiswa memiliki perangkat tersebut, sedangkan untuk smartphone $100 \%$ mahasiswa memilikinya. Sistem operasi umumnya digunakan oleh mahasiwa adalah Android OS dengan persentase $92,7 \%$. Hal ini berpotensi untuk menjadikan media pembelajaran berbasis Android bisa membantu mahasiswa dalam memahami materi trankripsi dan translasi.

\section{Analisis Peserta Didik}

Karakter mahasiswa secara garis besar adalah sebagai berikut:

1) Kemampuan akademis mahasiswa bersifat heterogen

2) Mahasiswa kesulitan memahami materi yang bersifat abstrak, konsep yang rumit, dan proses

3) Mahasiswa membutuhkan media pembelajaran yang mampu memvisualisasikan materi yang bersifat abstrak

4) Mahasiswa membutuhkan media pembelajaran yang praktis, bisa digunakan dimana saja dan kapan saja, serta dapat dijalankan secara offline.

\section{Analisis Tugas}

Capaian pembelajaran pada Rancangan Perkuliahan Semester (RPS) pada mata kuliah genetika II: (1) Mahasiswa mampu menganalisis protein yang terlibat, proses transkripsi dan pasca transkripsi; dan (2) Mahasiswa mampu menganalisis komponen yang terlibat, proses translasi dan pasca translasi

\section{Analisis Konsep}

Pada tahap ini dilakukan identifikasi pada konsep-konsep utama yang dimasukkan ke dalam media yang dikembangkan. Konsep-konsep tersebut kemudian disusun secara sistematis dan mengaitkan keterkaitan antar konsep sehingga didapatkan suatu peta konsep. Konsep-konsep yang disajikan pada media pembelajaran ini yaitu trankripsi, proses transkripsi, translasi, proses translasi, dan pasca translasi.

\section{Analisis Tujuan Pembelajaran}

Pada tahap ini dilakukan penyusunan tujuan pembelajaran berdasarkan kurikulum berbasis KKNI pada materi transkripsi dan translasi.

\subsection{Tahap Design}

Media pembelajaran berbasis Android ini dikembangkan menggunakan software Adobe Flash Professional CS6. Aplikasi ini dipilih untuk mengembangkan media pembelajaran ini karena aplikasi ini menggunakan action script 3.0 sehingga pengguna bisa membuat perintah sesuai keinginannya. Ditambah lagi dengan fitur AIR for Android, file yang dihasilkan dari aplikasi ini berupa file dengan format apk sehingga bisa dijalankan pada perangkat smartphone dengan sistem operasi Android. Media pembelajaran yang dikembangkan menggunakan aplikasi ini memungkinkan adanya interaksi antara media dan penggunanya sehingga dapat meningkatkan motivasi belajar peserta didik (Astuti \& Nurcahyo, 2019).

Hasil media pembelajaran berbasis Android menggunakan Adobe Flash Professional CS6 pada materi transkripsi dan translasi yang telah dikembangkan adalah sebagai berikut:

\section{Halaman Awal}

Pada halaman awal ini terdapat informasi awal seperti judul media, identitas pengembang dan pembimbing. Pada halaman ini terdapat tombol "masuk" untuk mulai menjalankan aplikasi. Saat halaman awal tampil juga ada suara narrator yang 
menjelaskan aplikasi secara umum dan perintah kegiatan selanjutnya (Gambar 1).

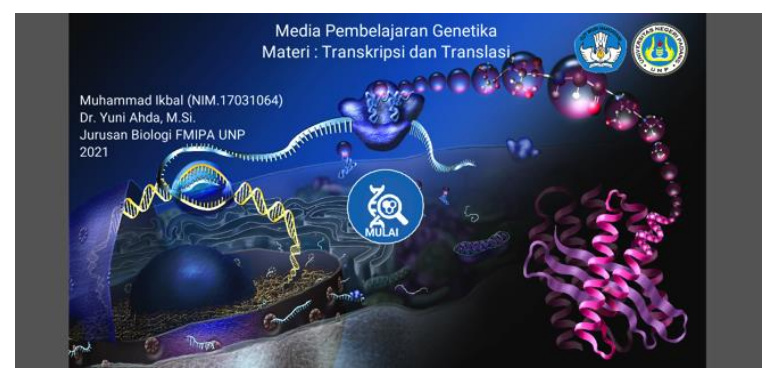

Gambar 1. Tampilan Halaman Awal

\section{Halaman Utama}

Pada halaman utama ini terdapat beberapa tombol menu yang terdiri dari: menu LO (Learning Outcomes atau capaian pembelajaran), materi, latihan dan tombol keluar. Semua tombol menu akan selalu tampil saat halaman tertentu muncul. Pada halaman utama ini menggunakan background berwarna hijau muda dengan tampilan DNA. Warna hijau dipilih untuk meminimalisir kelelahan mata (eye care) saat menggunakan media pembelajaran ini (Gambar 2).

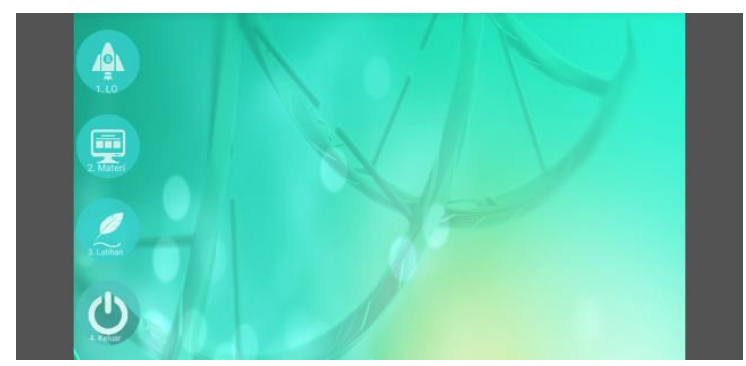

Gambar 2. Tampilan Halaman Utama

\section{Menu LO (Learning Outcomes)}

Pada menu ini ditampilkan capaian pembelajaran pada materi transkripsi dan translasi. Diakhir tampilan ini ada instruksi untuk lanjut ke menu berikutnya (Gambar 3).

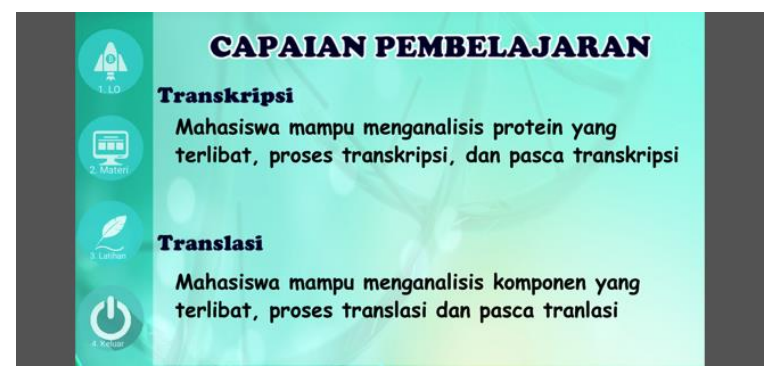

Gambar 3. Tampilan Menu LO

\section{Menu Materi}

Pada menu materi berisi materi transkripsi dan translasi berupa tulisan, grafis, animasi, dan suara untuk menjelaskan materi tersebut pada media pembelajaran ini. Materi bahasan terdiri dari transkripsi, proses trankripsi, translasi, proses translasi, dan pasca translasi. Disetiap tampilan pada menu materi akan ada instruksi untuk melanjutkan halaman selanjutnya atau tombol kembali ke halaman sebelumnya. Diakhir menu terdapat instruksi untuk lanjut ke menu selanjutnya. Materi yang disajikan berdasarkan konsep yang ada dalam buku teks dengan visualisasi yang disederhanakan (Gambar 4).

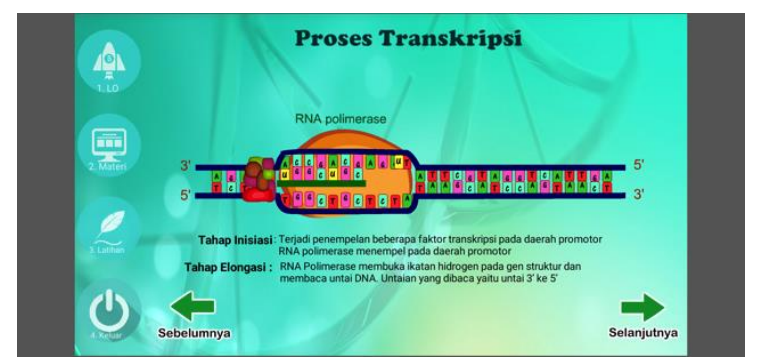

Gambar 4. Tampilan Menu Materi

\section{Menu Latihan}

Pada menu latihan terdapat sepuluh butir soal tipe multiple choises. Setiap halaman terdiri dari naskah soal, pilihan jawaban dilengkapi tombol jawaban dari A hingga $E$. Jika salah satu tombol jawaban dipilih maka secara otomatis tampilan akan beralih ke halaman selanjutnya. Diakhir 
tampilan pada menu latihan ini akan ditampilkan skor yang diperoleh oleh pengguna, dan keterangan apakah lulus atau belum sesuai dengan KKM yang telah ditetapkan (Gambar 5).

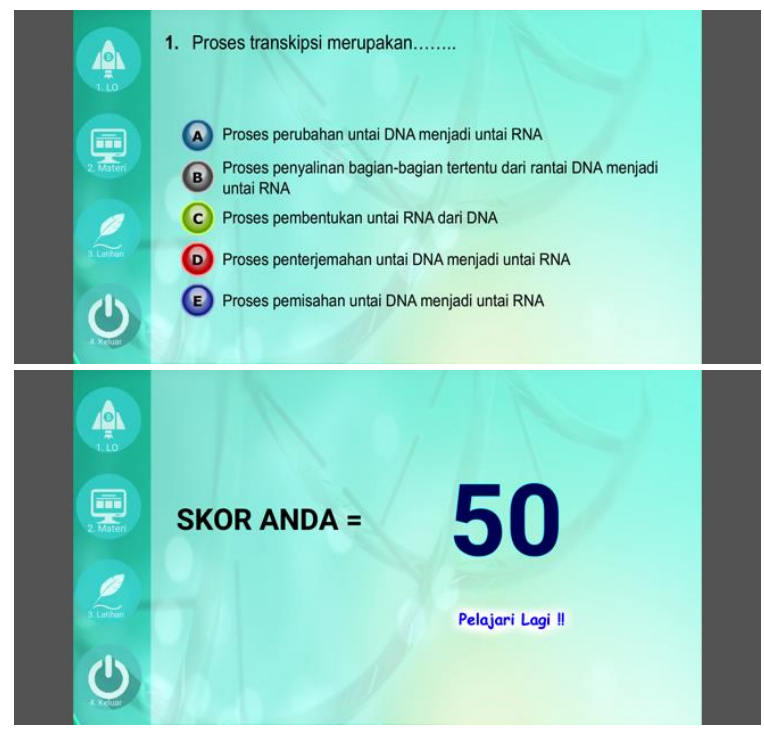

Gambar 5. Tampilan Menu Latihan

\section{Tombol Keluar}

Tombol ini digunakan untuk keluar dari media pembelajaran ini. Jika tombol ini diklik, maka secara otomatis sistem aplikasi media pembelajaran ini akan mengakhiri semua proses yang sedang dijalankan baik berupa animasi, grafis, maupun suara. Setelah keluar dari aplikasi media pembelajaran, tampilan pada smartphone penggunanya kembali ke tampilan menumenu yang terdapat pada menu home penggunanya.

\subsection{Tahap Develop}

Uji validitas media pembelajaran pada materi trankripsi dan translasi yang dikembangkan pada penelitian ini dilakukan oleh dua orang pakar yang terdiri dari ahli media dan ahli materi. Ahli media merupakan pakar dalam media pendidikan. Ahli materi merupakan pakar dalam genetika molekuler. Berikut merupakan rata- rata nilai hasil uji validitas dari ahli media dan ahli materi.

Tabel 3. Hasil Uji Validitas oleh Ahli Media

\begin{tabular}{|c|c|c|c|}
\hline No. & Aspek & $\begin{array}{c}\text { Persen- } \\
\text { tase }\end{array}$ & $\begin{array}{c}\text { Kate- } \\
\text { gori }\end{array}$ \\
\hline 1 & Kualitas tampilan & $88.8 \%$ & $\begin{array}{l}\text { Sangat } \\
\text { valid }\end{array}$ \\
\hline 2 & $\begin{array}{ll}\text { Kualitas } & \text { media } \\
\text { (kualitas } & \text { grafis, } \\
\text { animasi, } & \text { audio, } \\
\text { visual) } & \end{array}$ & $80 \%$ & Valid \\
\hline 3 & $\begin{array}{l}\text { Interface } \\
\text { (antarmuka } \\
\text { aplikasi) }\end{array}$ & $80 \%$ & Valid \\
\hline 4 & Keterlaksanaan & $86.7 \%$ & $\begin{array}{l}\text { Sangat } \\
\text { valid }\end{array}$ \\
\hline & Rata-Rata & $83.8 \%$ & $\begin{array}{l}\text { Sangat } \\
\text { valid }\end{array}$ \\
\hline
\end{tabular}

Tabel 4. Hasil Uji Validitas oleh Ahli Materi

\begin{tabular}{clcl}
\hline No. & \multicolumn{1}{c}{ Aspek } & $\begin{array}{c}\text { Persen- } \\
\text { tase }\end{array}$ & $\begin{array}{c}\text { Kate- } \\
\text { gori }\end{array}$ \\
\hline 1 & Kurikulum & $100 \%$ & $\begin{array}{l}\text { Sangat } \\
\text { valid }\end{array}$ \\
2 & Penyajian materi & $95 \%$ & $\begin{array}{l}\text { Sangat } \\
\text { valid }\end{array}$ \\
3 & Evaluasi & $95 \%$ & $\begin{array}{l}\text { Sangat } \\
\text { valid }\end{array}$ \\
4 & Kebahasaan & $100 \%$ & $\begin{array}{l}\text { Sangat } \\
\text { valid } \\
\text { Sangat } \\
\text { valid }\end{array}$ \\
\hline
\end{tabular}

Hasil analisis penilaian dari dua orang validator yang terdiri dari ahli genetika molekuler dan ahli media. Validasi produk dapat dilakukan dengan cara menghadirkan beberapa orang pakar atau ahli untuk memberikan penilaian terhadap produk yang telah dikembangkan (Rusman, 2011). Setiap pakar diminta menilai produk berdasarkan instrumen yang telah ditetapkan dan memberikan saran terhadap media sehingga dapat diketahui kelemahan dan kekurangan dari media.

Hasil validasi ditinjau dari ahli media menunjukkan produk yang telah dikembangkan memiliki kualitas tampilan yang sangat valid sebesar $88.8 \%$, kualitas 
media $80 \%$ dikategorikan valid, interface $80 \%$ dengan kategori valid, serta aspek keterlaksanaan $86.7 \%$ yaitu sangat valid. Dari keempat aspek tersebut didapatkan nilai rata-rata hasil validasi untuk ahli media sebesar $83.8 \%$ dengan kategori sangat valid.

Hasil penilaian dari ahli materi dengan aspek kurikulum sebesar 100\% dengan kategori sangat valid, penyajian materi 95\% yaitu sangat valid, evaluasi 95\% dapat dikategorikan sangat valid, dan aspek kebahasaan sangat valid sebesar 100\%. Dari keempat aspek tersebut bisa didapatkan nilai rata-rata hasil validasi untuk ahli materi sebesar $97.5 \%$ dengan kategori sangat valid.

Beberapa penelitian terkait penelitian ini yaitu: penelitian Rio Rasdian Saputra (2020) yang berjudul "Pengembangan EModule Berbasis Android menggunakan Adobe Flash Professional CS6 pada Materi Struktur dan Fungsi Jaringan Tumbuhan serta Sistem Sirkulasi untuk Peserta Didik Kelas XI MIPA SMAN 3 Padang", hasil penelitian ini menunjukkan e-module berbasis Android sangat valid dengan nilai 83,52\%. Hasil penelitian Syarifah Aini (2020) yang berjudul "Pengembangan Media Pembelajaran Berbasis Android Menggunakan Adobe Flash Professional CS6 tentang Materi Interaksi Makhluk Hidup dan Lingkungan untuk Peserta Didik Kelas VII SMP/MTs" diperoleh nilai validitas ratarata yaitu $93,70 \%$ dengan kriteria sangat valid. Penelitian Anggi Yanuariska (2005) yang berjudul "Pengembangan Media Pembelajaran Berbasis Chemistry Triangle Menggunakan Aplikasi Android untuk Materi Elektrokimia Kelas XII SMA/MA" hasil penelitian ini menunjukkan rata-rata nilai validitas sebesar 0,87 dengan kategori sangat valid. Penelitian Sri Ratu Rahayu (2017) yang berjudul "Pengembangan
Media Pembelajaran Berbasis Android Menggunakan Adobe Flash CS6 untuk Mata Pelajaran Matematika". Hasil penelitian yang didapatkan berupa uji validitas dengan skor 0,948 pada aspek materi, skor 0,831 pada aspek media dengan kategori valid.

Media pembelajaran merupakan sarana untuk mentransfer ilmu pengetahuan atau informasi dari pendidik ke peserta didik. Media pembelajaran adalah alat bantu baik berupa fisik maupun non-fisik yang sengaja digunakan oleh pendidik untuk membantu peserta didik memahami materi (Miftah, 2013). Perkembangan teknologi juga berdampak terhadap dunia pendidikan, salah satunya dimanfaatkan sebagai media pembelajaran berbasis Android. Media pembelajaran berbasis Anroid selain praktis dan fleksibel dalam penggunaannya, salah satu keunngulan lainnya ialah bisa dilengkapi dengan multimedia. Media pembelajaran menggunakan multimedia dapat meningkatkan efektivitas pembelajaran karena dengan menggunakan teknologi seorang pendidik bisa mempersingkat waktu untuk menjelaskan materi; penggunaan gambar, animasi, dan video dapat meningkatkan minat belajar peserta didik dan mempermudah peserta didik dalam memahami materi; dan memfasilitasi peserta didik untuk mencapai tujuan atau capaian pembelajaran (Ningsih, Miarsyah, \& Rusdi, 2019).

Media pembelajaran yang baik harus memenuhi empat kriteria yaitu: kesesuaian (relevansi), kemudahan, kemenarikan, dan kemanfaatan (Noviar, 2016). Berdasarkan penilaian dari kedua aspek diatas, didapatkan nilai rata-rata validitas media yang telah dikembangkan sebesar $91.2 \%$ dengan kategori sangat valid. Media pembelajaran berbasis Android yang telah dikembangkan dinyatakan valid. Media ini 
telah memenuhi empat kriteria diatas dan dapat digunakan untuk uji praktikalitas.

Beberapa komponen yang harus diperbaiki sesuai saran validator adalah sebagai berikut:

1) Mengurangi penggunaan warna merah dan biru

2) Memperdalam sajian materi dan ubah beberapa soal yang rancu

3) Perbaiki tulisan yang terpisah dari tulisan yang lainnya

4) Memberi nomor pada setiap tombol menu

5) Memberikan suara instruksi untuk perintah selanjunya

6) Geser sedikit ke atas tombol navigasi "sebelumnya" dan "selanjutnya"

7) Samakan volume suara narrator

\section{KESIMPULAN}

Berdasarkan pengembangan media pembelajaran berbasis Android dan hasil uji valditas yang telah dilakukan dapat disimpulkan bahwa media pembelajaran berbasis Android menggunakan Adobe Flash Professional CS6 pada materi transkripsi dan translasi telah memenuhi kualitas produk yang valid dengan persentase skor $91,2 \%$ dengan kategori sangat valid, dan dapat ditindak lanjuti dengan uji praktikalitas.

\section{Daftar Pustaka}

Arikunto, S., \& Jabar. (2012). Dasar-Dasar Evaluasi Pendidikan. Jakarta: Bumi Aksara.

Astuti, E., \& Nurcahyo, H. (2019). Development of Biology Learning Media Based on Adobe Flash to Increase Interest and Conceptual Understanding. Journal Physics: Conference Series , 1-8.
Cavalho, J. C., Beltramini, L. M., \& Bossolan, N. R. (2018). Using a Bord Game to Teach Protein Synthesis to High School Student. Journal of Biological Education , 1-12.

Fadri, R., Ahda, Y., Zulyusri, \& Sumarmin, R. (2018). Needs Analysis of Development Interactive Multimedia Learning Based Android on Molecular Genetic Material in University. International Journal of Progressive Sciences and Technologies (IJPSAT), Vol. 6 (No.2), 488-492.

Fitriana, D. E., Amelia, E., \& Marianingsih, P. (2017). Penyusunan Modul Pembelajaran Berbasis Sains Teknologi dan Masyarakat (STM) Pada Konsep Bioteknologi (Sebagai Bahan Ajar Siswa SMA Kelas XII). BIOSFER: Jurnal Pendidikan Biologi (BIOSFERJPB) , 10 (2), 60-72.

Haryono, A., Basuki, B., Adam, C., Savitri, S., Araina, E., \& Fahrina, R. (2021). The Development of eLEMA-SCL Protozoa for Invertebrate Zoology Courses. International Conference on Elementary Education, 3(1), 212-218. Retrieved from http://proceedings2.upi.edu/index.php/ic ee/article/view/1465

Mahmudati, N. (2015). Pengembangan Mutu Pembelajaran untuk Meningkatkan Prestasi Mahasiswa pada Bidang Studi Genetika Dasar Melalui Lesson Study. Prosiding Seminar Nasional Pendidikan Biologi (pp. 504-509). Malang: Prodi Pendidikan Biologi FKIP Universitas Muhammadiyah Malang.

Miftah, M. (2013). Fungsi, dan Peran Media Pembelajaran Sebagai Upaya Peningkatan Kemampuan Belajar Siswa. Jurnal Kwangsan , 2 (1), 95105. 
Munir. (2012). MULTIMEDIA: Konsep \& Aplikasi dalam Pendidikan. Bandung: Penerbit Alfabeta.

Ningsih, L. R., Miarsyah, M., \& Rusdi, R. (2019). Interactive media of respiratory system material "resymart" based on problem-based learning. JPBI (Jurnal Pendidikan Biologi Indonesia) , 459470.

Noviar, D. (2016). Pengembangan Ensiklopedi Biologi Moile Berbasis Android Materi Pokok Pteridophyta dalam Rangka Implementasi Kurikulum 2013. Cakrawala Pendidikan , XXXV (2), 198-207.

Pahlifi, D. M., \& Fatharani, M. (2019). Android-Based Learning Media on Human Respiratory System Material for High School Students. Jurnal Inovasi Pendidikan IPA , 109-116.

Rusman. (2011). Pembelajaran Berbasis TIK: Mengembangkan Profesionalitas Guru. Jakarta: PT. Raja Grafindo Persada.

Setiana, H., \& Hansun, S. (2017). Gamified Android Based Academic Information System. International Journal of Evaluation and Research in Education (IJERE) , 6 (2), 164-173.

Setiawan, H., Alimi, M. S., Alimah, S., Kurniawan, F. H., \& Zahro, R. N. (2015). Implementating Contextual Biology Game Learning (CBGL) in Digital Era with Pterodovela in Smartphone to Improving Senior High School Student's Abilities in Learning Diversity of Bryophyta and Pterodophyta in Indonesia. PEOPLE: International Journal of Social Science , 197-212.

Sophia, A., Yensasnidar, \& Hardiansyah, N. (2019). Analisis Kebutuhan Pengembangan Multimedia Interaktif
Berbasis Android untuk Mahasiswa Teknologi Laboratorium Medis (TLM). Jurnal IPTEKS Terapan , 13 (3), 186194.

Statcounter. (2020, August). Mobile Operating System Market Share in Indonesia November 2019 - November 2020. Dipetik 11 6, 2020, dari Statcounter GlobalStats: https://gs.statcounter.com/os-marketshare/mobile/indonesia

Suryanda, A., Ernawati, \& Maulana, A. (2016). Pengembangan Modul Multimedaia Mobile Learning dengan Android Studio 4.1 Materi Keanekaragaman Hayati Bagi Siswa SMA Kelas X. Biosfer: Jurnal Pendidikan Biologi (BIOSFERJPB), 9 (1), 55-64.

Thiagarajan, S., Semmel, D., \& M. (1974). Instructional Development for Training Teachers of Exceptional Children: A Sourcebook. Washington D.C.: Bloomington: Indiana University.

Yektyastuti, R., \& Ikhsan, J. (2016). Pengembangan Media Pemebelajaran Berbasis Android pada Materi Kelarutan untuk Meningkatkan Performa Akademik Peserta Didik SMA. Jurnal Inovasi Pendidikan IPA , 2 (1), 88-99.

Zaheer, S., Butt, S. M., Anatolyevna, G. V., \& Salmani, H. (2018). Do Mobile Technology in the Classroom Really Improve Learning Outcomes? International Journal of Evaluation and Research in Education (IJERE) , 7 (3), 188-193. 